\title{
Dynamics of production and forage utilization on elephant grass pastures managed with different post-grazing heights ${ }^{1}$
}

\section{Braulio Maia de Lana Sousa ${ }^{2}$, Domicio do Nascimento Júnior ${ }^{2}$, Hélida Christhine de Freitas Monteiro $^{3}$, Dilermando Miranda da Fonseca ${ }^{2}$}

\author{
${ }^{1}$ Financed by FAPEMIG. Support: CNPq. \\ 2 Departamento de Zootecnia - UFV, Viçosa, MG. \\ ${ }^{3}$ Departamento de Ciências Agrárias - UNIMONTES, Janaúba, MG.
}

\begin{abstract}
This study was conducted to evaluate the daily production of forage and its morphological components, as well as the potential of forage utilization in pastures of Pennisetum purpureum cv. Napier managed with three post-grazing heights (30, 50 and $70 \mathrm{~cm}$ ). Two experiments were carried out: one from February to May 2009 and another from December 2009 to May 2010, characterizing months of summer and fall. The experimental design was of completely randomized blocks with three replicates. The grazing was performed by crossbred heifers of approximately $270 \mathrm{~kg}$ body weight, when the sward intercepted $95 \%$ of the incoming light. In both experiments, the pastures managed with post-grazing height of $30 \mathrm{~cm}$, in the summer months (December to March), presented lower daily production of leaves and stems, as well as less daily leaf senescence, which resulted in lower daily forage production and accumulation in comparison with those managed at 70 and $50 \mathrm{~cm}$. In the period from February to March 2009 (experiment 1) and December 2009 to March 2010 (experiment 2), pastures presented greater daily production of leaves and forage, greater daily forage accumulation and more daily leaf senescence in relation to the months of April and May 2009 and 2010. On the other hand, the daily production of stems was higher in the fall, in comparison with the summer. Therefore, elevation in the post-grazing height, especially in the summer, increases the regrowth vigor of elephant grass cv. Napier.
\end{abstract}

Key Words: light interception, pasture management, pasture structure, Pennisetum purpureum

\section{Introduction}

Elephant grass (Pennisetum purpureum Schum.) is a perennial grass, with caespistose growth which can form dense tussocks by means of abundant basal and aerial tillering. Very demanding when it comes to fertility, it does not tolerate poorly drained or acid soils, or soils with high aluminum concentration (Alcântara \& Bufarah, 1983; Jacques, 1994). Because of its high productive potential and nutritional value, as well as flexibility to use, it stands out as one of the most important grasses of Brazil. However, in grazing, grasses of the genus Pennisetum are deprecated in relation to those of the genera Panicum and Brachiaria, partly because of the lack of knowledge of the appropriate management for elephant grass.

Historically, the management of elephant grass under pasture has been recommended based on the utilization of fixed rest periods or animal entry heights of 1.70-1.80 m (Deresz et al., 2006), which is a type of management that hampers control of the stem elongation and leaf senescence processes (Da Silva \& Nascimento Júnior, 2007).
Currently, the interception of $85 \%$ of light by the forage sward has been described as the ideal moment for interruption of regrowth, for determining maximum forage accumulation, with effective control of the processes of stem elongation and leaf senescence (Nascimento Júnior et al., 2010). When the defoliation frequency is defined, the flexibility of pasture management can be generated by means of variations in the post-grazing height utilized. On the one hand, the removal of mature tissues and reduction in the intraspecific competition for light in response to defoliation can benefit the forage plant. Contrarily, when severe, the defoliation can be harmful to the plant by the removal of apical meristems (Korte \& Harris, 1987), reduction in the leaf area (Brougham, 1956) and mobilization of organic reserves (Davidson \& Milthorpe, 1966).

Thus, the study of the daily production of forage and its components allow the obtainment of important information that can help the determination of adequate management practices to elephant grass, increasing its importance for use in pastures. The study has been proposed in order to evaluate the post-grazing heit effect on elephant grass cv. Napier, aiming to establish rational goals of management for this forage plant under rotational stocking. 


\section{Material and Methods}

The experiment was conducted in an area of the Forage Sector of Universidade Federal de Viçosa (UFV), in Viçosa, Minas Gerais, Brazil (20 45' S; 42 ${ }^{\circ} 51^{\prime} \mathrm{W}$ and $651 \mathrm{~m}$ ), with elephant grass cv. Napier (Pennisetum purpureum Schum.). According to the Köppen (1948) classification, the climate is of Cwa subtropical type, with dry (in the coldest months) and rainy (in the summer) well-defined seasons. Information on the climate (Figure 1) was obtained at the meteorological station of UFV, approximately 1,000 away from the experimental area. The monthly water balance (Figure 2) was calculated utilizing a water holding capacity (WHC) of $50 \mathrm{~mm}$ (Thornthwaite \& Mather, 1955).

The soil is classified as a Red-Yellow Argissoil of open clayey texture (EMBRAPA, 1999), and according to the results of the chemical analysis (Raij et al., 1986), conducted in December 2007, in the 0-20 cm layer, it presented the following characteristics: $\mathrm{pH}$ in $\mathrm{H}_{2} \mathrm{O}=5.3 ; \mathrm{P}=1.7$ (Mehlich-1) and $\mathrm{K}=34 \mathrm{mg} / \mathrm{dm}^{3} ; \mathrm{Ca}^{+2}=2.0 ; \mathrm{Mg}^{+2}=0.9 ; \mathrm{H}+\mathrm{Al}=4.79$; CEC $(\mathrm{T})=7.8 \mathrm{cmol}_{\mathrm{C}} / \mathrm{dm}^{3} ; \mathrm{V}=38 \%$. With the results, the appropriate corrections and fertilizations were done aiming to elevate the base saturation to $50-70 \%$, the phosphorus content to $8-12 \mathrm{mg} / \mathrm{dm}^{3}$ and the potassium content to $80-100 \mathrm{mg} / \mathrm{dm}^{3}$ (CFSEMG, 1999). Moreover, the equivalent of $200 \mathrm{~kg} / \mathrm{ha}$ nitrogen was applied in portions, in the form of ammonium sulfate.

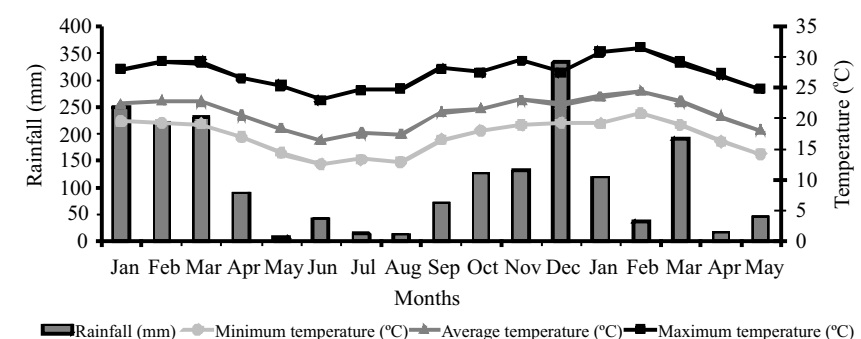

Figure 1 - Monthly accumulated rainfall and minimum, maximum and mean air temperatures in the period from January 2009 to May 2010.

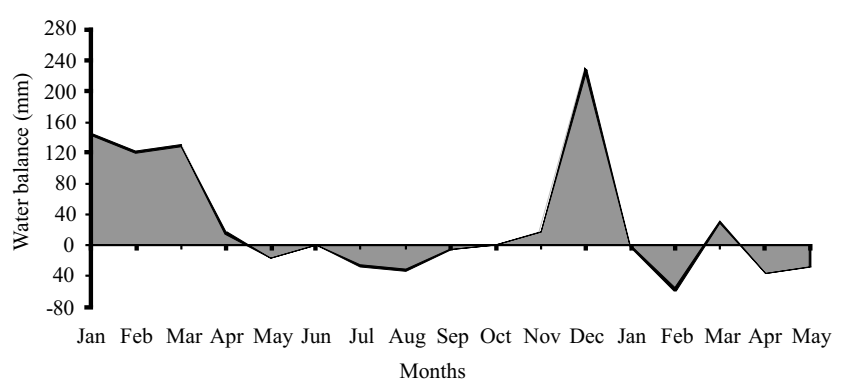

Figure 2 - Monthly water balance from January 2009 to May 2010.
Because of the early lengthening of the apical meristem of elephant grass cv. Napier and the high aerial tillering after the decapitation of the apical meristem of basal tillers, originally formed in the beginning of all the growth season, two experiments were conducted to evaluate three postgrazing residue heights: 30,50 or $70 \mathrm{~cm}$, assumed to characterize severe, intermediate and lenient defoliations and forage utilization levels, respectively. In the first one, conducted from February to May 2009, the moment for animals to enter the paddocks was determined by the level of light interception by the sward. Thus, animals only started grazing when the light interception reached 95\%, and it was interrupted when the sward reached residue heights of 30, 50 or $70 \mathrm{~cm}$. In the second experiment, conducted from December 2009 to May 2010, the first grazing session was performed when the apical meristems of basal tillers were at 30,50 and $70 \mathrm{~cm}$, regardless of the level of light interception by the sward. This strategy aims to eliminate the apical meristems from the basal tillers, stimulating quick and vigorous regrowth originated from axillary buds (Corsi, 1993). For the entry of animals in the subsequent grazing session, the level of light interception was, once more, the determinant factor for the performance of grazing. The post-grazing heights were allocated to experimental units (400 $\mathrm{m}^{2}$ paddocks) according to completely randomized blocks design with three replicates.

The monitoring of the light interception was performed throughout the regrowth period, with interval of seven days between assessments. However, when the forage sward intercepted above $90 \%$ of the incoming radiation, the monitoring interval was reduced to two days, until reaching 95\% light interception, which was the moment for grazing. Light interception was measured with sward analyzer device (LAI 2000, LI-COR, Lincoln, Nebraska, USA) at four random spots per experimental units. Each spot was composed of a reading above the sward and five on the soil surface (below the sward).

The evaluation of the apical meristem of basal tillers was performed at every seven days, and this interval was reduced to two days as the height of apical meristems approached the goals set. For so, 20 basal tillers were cut close to the soil level. Subsequently, these tillers were vertically selected for visualization of the location of their apical meristem. The measurement of the apical meristem was done by measuring the distance from the base of the sward to the meristem apex.

During the experiments, fertilization was done with nitrogen, in a split manner, in the period favorable to forage plant growth (January to March). In the end of this period, $200 \mathrm{~kg} / \mathrm{ha}$ nitrogen were constantly applied post-grazing in 
the form of ammonium sulfate. Since the grazing interval and the condition of animal entry on pastures were not fixed, the amount of fertilizer that each paddock received at each grazing cycle was variable. Thus, the $200 \mathrm{~kg} / \mathrm{ha}$ nitrogen were divided by the growth period of the forage plant (January to March), thus obtaining the daily amount that should be applied on each paddock. The amount of fertilizer effectively applied was obtained by multiplying this daily amount by the rest period occurring in each experimental period. Therefore, at the end of each experiment, all pastures received the same amount of nitrogen (200 kg/ha).

Grazing was performed by crossbred heifers of approximately $270 \mathrm{~kg}$ body weight by utilizing the mob grazing method (Mislevy et al., 1983). Animal lots were sized so that the grazing period would be of four to six hours. After leaving the paddocks, animals remained on reserve pastures and only returned to the experiment when paddocks reached the pre-grazing condition once more.

For the estimate of production and daily forage accumulation, several tillers were tagged in all experimental units and throughout the experiment (Grant \& Marriot, 1994). After each grazing session, 12 tillers were tagged randomly. In representative points of the average sward condition (visual assessment of height and forage mass), one tagged stalk, in regular distance intervals, was allocated parallel to the soil. This way, the tiller closest to tagging was chosen to be monitored; the tiller could be basal or aerial. In addition, aerial tillers emerging throughout regrowth, on the 12 tillers initially tagged, were also monitored. Tillers were evaluated twice weekly, by means of measurements of the length of leaf blades and pseudostem (stem + leaf sheaths). Such evaluations allowed to estimate the leaf and stem elongation rates and leaf senescence rate ( $\mathrm{cm} /$ tiller.day) (Lemaire \& Chapman, 1996).

The linear values $(\mathrm{cm})$ of elongation and senescence rates were converted into weight values per area unit by utilizing a conversion factor. On the last day of every evaluation period, all tillers tagged were cut at the soil level (basal tillers). These tillers were placed in plastic bags and immediately taken to cold chamber to minimize the losses by respiration and evaporation. After measurement of stems and leaves similarly to the procedures on field, all leaf sheaths of each tiller and their respective stems were ovendried ( $65{ }^{\circ} \mathrm{C}, 72$ hours). After drying, the material was weighed and the mass of each component was divided by its respective total length. Thus, a conversion factor $(\mathrm{mg} / \mathrm{cm})$ was generated, utilized to transform all the field reading, expressed in cm/tiller.day, into $\mathrm{mg} /$ tiller.day. The final transformation into kg/ha.day of dry forage mass was done by multiplying these values by tiller population density in each experimental unit, which was obtained by means of counting live tillers inside four metallic frames of $0.25 \mathrm{~m}^{2}$ $(0.25 \times 1.00 \mathrm{~m})$, located at representative points of the average sward condition before the start of grazing. This way, the linear values of elongation of leaves, stems and senescence were transformed into daily leaf and stem production and daily leaf senescence ( $\mathrm{kg} / \mathrm{ha}$.day DM). The sum of the daily leaf and stem production originated the daily forage production, and the difference between daily forage production and leaf senescence values enabled the calculation of daily forage accumulation. From the values of daily forage production and senescence, it was possible to estimate the forage utilization potential [(1-senescence/ forage production $) \times 100]$ (Bircham \& Hodgson, 1983)

The data were organized according to month of the year and submitted to variance analysis with the feature MIXED of statistical package SAS (Statistical Analysis System, version 8.2), for Windows. All the data set was tested so as to ensure that the basic prerogatives of the variance analysis were met. At the selection of the variance and covariance matrices, the Akaike information criterion (Wolfinger, 1993) was utilized. Therefore, it was possible to detect the effects of main reasons of variation (post-grazing heights and month) and the interaction between them. The effects of post-grazing heights, month of the year and their interactions were considered fixed, and the blocks effect and their interaction were considered random (Littel et al., 2000). The means of the treatments were estimated by the feature LSMEANS and compared utilizing Student $\mathrm{T}$ test with $5 \%$ significance.

\section{Results and Discussion}

Post-grazing heights were close to the intended goals and the values achieved are presented descriptively (Table 1). Overall, the sward height at pre-grazing condition varied between 90.0 and $100.0 \mathrm{~cm}$ (Monteiro, 2011)

In experiment 1 , there was post-grazing height $\times$ month interaction for daily leaf production $(\mathrm{P}=0.0340)$. Pastures managed with post-grazing height of 70 and $50 \mathrm{~cm}$ presented greater daily leaf production between February and April 2009 in comparison with those managed at $30 \mathrm{~cm}$; differences were over in May. Overall, the daily leaf production was elevated in February and March, in relation to April and May (Table 2).

In experiment 2 , there was post-grazing $\times$ month interaction for the daily leaf production $(\mathrm{P}<0.0001)$. In the beginning of the experiment, in December 2009, pastures 
Table 1 - Post-grazing heights in elephant grass cv. Napier pastures

\begin{tabular}{lccc}
\hline Months & \multicolumn{3}{c}{ Post-grazing heights $(\mathrm{cm})$} \\
\cline { 2 - 4 } & 30 & 50 & 70 \\
\hline & \multicolumn{3}{c}{ Experiment 1} \\
February 2009 & 29.4 & 49.5 & 67.8 \\
March 2009 & 29.0 & 50.5 & 68.7 \\
April 2009 & 30.4 & 50.0 & 69.4 \\
May 2009 & 31.0 & 51.3 & 68.0 \\
& & Experiment 2 & \\
December 2009 & 30.4 & 53.4 & 70.2 \\
January 2010 & 32.2 & 49.1 & 70.4 \\
February 2010 & 31.3 & 50.4 & 70.7 \\
March 2010 & 32.4 & 51.2 & 71.2 \\
April 2010 & 31.8 & 50.9 & 70.8 \\
May 2010 & 32.5 & 50.5 & 70.5 \\
\hline
\end{tabular}

Table 2 - Daily production of leaves and stems of elephant grass cv. Napier subjected to three post-grazing heights when reaching 95\% light interception during regrowth

\begin{tabular}{lccc}
\hline Months & \multicolumn{2}{c}{ Post-grazing heights $(\mathrm{cm})$} & \multirow{2}{*}{ SEM } \\
\cline { 2 - 3 } & 30 & 50 & 70
\end{tabular}

Daily production of leaves (kg/ha.day DM)

\begin{tabular}{|c|c|c|c|c|}
\hline \multicolumn{5}{|c|}{ Experiment 1} \\
\hline February 2009 & 76.3Ab & 163.3Аa & $173.7 \mathrm{Aa}$ & 15.65 \\
\hline March 2009 & $50.2 \mathrm{ABb}$ & $116.5 \mathrm{Ba}$ & 111.9Ва & 10.98 \\
\hline April 2009 & 21.2BCb & $31.3 \mathrm{Ca}$ & $34.4 \mathrm{Ca}$ & 2.05 \\
\hline May 2009 & $14.6 \mathrm{Ca}$ & $19.2 \mathrm{Da}$ & 17.3Da & 1.26 \\
\hline \multicolumn{5}{|c|}{ Experiment 2} \\
\hline December 2009 & $44.2 \mathrm{Ab}$ & $76.9 \mathrm{Aa}$ & $65.4 \mathrm{Ba}$ & 6.73 \\
\hline January 2010 & $32.2 \mathrm{Abc}$ & $70.3 \mathrm{Ab}$ & $97.8 \mathrm{Aa}$ & .73 \\
\hline February 2010 & $29.5 \mathrm{Abc}$ & $52.9 \mathrm{Bb}$ & $100.9 \mathrm{Aa}$ & 6.73 \\
\hline March 2010 & 31.7Abc & 49.8BCb & $78.9 \mathrm{Ba}$ & 6.73 \\
\hline April 2010 & 30.0Aba & $40.2 \mathrm{BCa}$ & $43.9 \mathrm{Ca}$ & 6.73 \\
\hline May 2010 & $28.6 \mathrm{Ba}$ & $35.7 \mathrm{Ca}$ & $37.3 \mathrm{Ca}$ & 6.73 \\
\hline \multicolumn{5}{|c|}{ Daily production of stems (kg/ha.day DM) } \\
\hline \multicolumn{5}{|c|}{ Experiment 1} \\
\hline February 2009 & $39.7 \mathrm{Ab}$ & $149.9 \mathrm{Aa}$ & 145.9Aa & 10.23 \\
\hline March 2009 & $45.8 \mathrm{Ab}$ & $137.5 \mathrm{Aa}$ & $142.4 \mathrm{Aa}$ & 12.64 \\
\hline April 2009 & $49.5 \mathrm{Aa}$ & $69.1 \mathrm{Ba}$ & $42.5 \mathrm{Ba}$ & 11.49 \\
\hline May 2009 & 22.9Aa & $28.6 \mathrm{Ca}$ & 39.8Ba & 11.98 \\
\hline \multicolumn{5}{|c|}{ Experiment 2} \\
\hline December 2009 & $25.2 \mathrm{Bb}$ & $46.9 \mathrm{BCa}$ & $47.5 \mathrm{Ba}$ & 5.61 \\
\hline January 2010 & 21.9BCс & $45.7 \mathrm{BCb}$ & $81.9 \mathrm{Aa}$ & 5.61 \\
\hline February 2010 & & & 70.8Aba & 5.61 \\
\hline March 2010 & 40.3Ac & 53.9ABb & $77.9 \mathrm{Aa}$ & 5.61 \\
\hline April 2010 & $34.1 \mathrm{ABb}$ & $65.8 \mathrm{Aa}$ & $81.6 \mathrm{Aa}$ & 5.61 \\
\hline May 2010 & $9.8 \mathrm{Cb}$ & $52.4 \mathrm{Ba}$ & $55.7 \mathrm{Ba}$ & 5.61 \\
\hline
\end{tabular}

For each characteristic, means followed by the same uppercase letter in the column and lowercase letter in the row do not differ significantly based on Student's $t$-test $(\mathrm{P}>0.05)$.

SEM - standard error of the mean. managed with post-grazing height of 70 and $50 \mathrm{~cm}$ presented greater daily leaf production in relation to those managed at $30 \mathrm{~cm}$. From January to March 2010, higher values were recorded in pastures managed with post-grazing height of $70 \mathrm{~cm}$, intermediate in those managed at $50 \mathrm{~cm}$ and lower in the pastures managed at $30 \mathrm{~cm}$. These differences were gone in April and May. Overall, daily leaf production was elevated in the summer (December to March), in comparison with the fall (April and May) (Table 2).

In experiment 1 , the daily production of stems was affected by the post-grazing height $\times$ month interaction $(P=0.0010)$. Higher values have been recorded on pastures managed with post-grazing height of 70 and $50 \mathrm{~cm}$ in February and March 2009, in comparison with those managed at $30 \mathrm{~cm}$. These differences disappeared in April and May. Except for pastures managed at post grazing height of $30 \mathrm{~cm}$, greater daily production of stems was obtained in January and February in relation to March and April (Table 2).

In experiment 2, there was post-grazing height and month interaction for the daily production of stems $(\mathrm{P}=0.0014)$. In the beginning of the experiment, in December 2009, pastures managed at post grazing height of 70 and 50 presented greater daily production of stems in relation to those managed at $30 \mathrm{~cm}$. From January to March 2010, greater values were recorded in pastures managed at $70 \mathrm{~cm}$, intermediate in those managed at $50 \mathrm{~cm}$ and lower in those managed at $30 \mathrm{~cm}$. From April to May, pastures managed with post grazing heights of 70 and $50 \mathrm{~cm}$ presented higher values in comparison with those managed at $30 \mathrm{~cm}$ (Table 2). Overall, the daily production of stems increased in March and April, except for pastures managed with post-grazing height of $70 \mathrm{~cm}$, which presented elevated production from January to April.

The plant responses to the disturbance of defoliation must be understood as a mechanism of reestablishment and maintenance of the growth patterns, in which all factors available should be used for the formation of new photosynthesizing tissues (Lemaire \& Chapman, 1996). Regardless of the management strategy utilized (experiment 1 or 2), pastures managed with post-grazing height of $30 \mathrm{~cm}$ presented, during the months of summer, lower daily leaf and stem production (Table 2). More severe grazing removes more forage, increasing the quantity and quality of the light within the sward. In spite of this change in the luminous environment, the initial regrowth is slow due to the reduced remaining leaf area (Brougham, 1956) associated to its 
lower photosynthetic capacity after grazing (Parsons \& Penning, 1988; Braga et al., 2009). Besides, severe grazing promotes greater tiller decapitation, so there is the need for differing and dividing new cells for the formation of new meristems, and consequently tillers (Taiz \& Zeiger, 2009), which also contributed to lower daily leaf and stem production.

Environmental conditions, especially photoperiod, temperature and soil moisture present interference on pasture growth and development rates (Lemaire \& Chapman, 1996). In this sense, reduction in the daily production of leaves in the fall (April and May), in relation to the summer, is consistent with the occurrence of lower temperatures, reduced rainfall (Figures 1 and 2) and low luminosity (short days). Thus, in order to stay alive, the plant needs to reduce its growth flow as a way to save its organic reserves. In addition, in the fall there is flourishing of elephant grass cv. Napier. During the reproductive phase, there are changes in the translocation patterns of photoassimilates, so that the stems becomes a strong photoassimilate drain, which results in elevated internode elongation (Taiz \& Zeiger, 2009) and, consequently, greater production of stems than of leaves.

However, as opposed to the expectations, in experiment 1 , there was reduction in the daily stem production during the fall. In a more detailed analysis, it could be observed that the values obtained in February and March 2009 were elevated in comparison with the summer months of experiment 2. Although the statistical comparison between the experiments was not conducted due to the existence of several factors that could lead to confusion of the responses found (start of one experiment in February 2009 and of the other in December; distinct experimental periods; existence of differences in the weather conditions between the years), the strategy of decapitating most of the apical meristems at once (experiment 2) seems to have been more efficient at controlling the growth of stems in comparison with the other management strategy (experiment 1). Even contributing with forage accumulation, the stem accumulation is in most part, undesirable, once it causes expenditure of energy for growth and maintenance of this fraction, which, in addition to hampering the adequate and uniform lowering of the pasture by means of grazing (Carnevalli et al., 2006), negatively affects the nutritional value of the forage produced (Van Soest, 1994).

However, despite the relevance of this study, it is worth stressing the need of further research with this approach, but with longer experimental duration and assessing animal performance, so that practical management recommendations can be made.
In experiment 1 , daily leaf senescence was affected by the post-grazing height and time of the year interaction $(P=0.0288)$. In February 2009, there was contrast between post-grazing heights of 70 and $30 \mathrm{~cm}$, with higher value recorded in pastures managed at $70 \mathrm{~cm}$, lower in those managed at $30 \mathrm{~cm}$ and intermediate in those managed at $50 \mathrm{~cm}$. These differences disappeared in the following months. Pastures managed with post-grazing heights of $70 \mathrm{~cm}$ presented lower daily leaf senescence in April and May (Table 3).

In experiment 2, there was post-grazing height and month of the year interaction for daily leaf senescence $(\mathrm{P}=0.0265)$. In the beginning of the experiment, in December 2009, pastures managed with post-grazing height of 70 and $50 \mathrm{~cm}$ presented greater values in comparison with those managed at $30 \mathrm{~cm}$. In January and February 2010, greater daily leaf senescence was obtained in pastures managed with post-grazing height of $70 \mathrm{~cm}$, intermediate in those managed at $50 \mathrm{~cm}$ and lower in pastures managed with post-grazing height of $30 \mathrm{~cm}$. From March to May, higher value was recorded in pastures managed with post-grazing height of $70 \mathrm{~cm}$ in relation to those managed at 50 and $30 \mathrm{~cm}$. Overall, greater leaf senescence was observed from January to March (summer), reducing in April and May (fall) (Table 3).

Senescence is a natural process for which there is a genetic programming of the plant and which causes loss of chlorophyll, RNA and proteins, including enzymes, to plants (Salisbury \& Ross, 1992), provoking change of the coloration of the leaf tissue to yellowish, then brownish and darkish tones (Wilman \& Mares Martins, 1977). The senescence

Table 3 - Daily leaf senescence (kg/ha.day DM) of elephant grass cv. Napier subjected to three post-grazing heights when reaching 95\% light interception during regrowth

\begin{tabular}{|c|c|c|c|c|}
\hline \multirow[t]{2}{*}{ Months } & \multicolumn{3}{|c|}{ Post-grazing heights $(\mathrm{cm})$} & \multirow[t]{2}{*}{ SEM } \\
\hline & 30 & 50 & 70 & \\
\hline & \multicolumn{3}{|c|}{ Experiment 1} & \\
\hline February 2009 & $22.3 \mathrm{Ab}$ & 28.6Aab & 55.6Aa & 7.38 \\
\hline March 2009 & $23.3 \mathrm{Aa}$ & $31.5 \mathrm{Aa}$ & $43.5 \mathrm{Aa}$ & 7.66 \\
\hline April 2009 & $24.1 \mathrm{Aa}$ & $18.7 \mathrm{Aa}$ & $20.3 \mathrm{Ba}$ & 4.21 \\
\hline \multirow[t]{2}{*}{ May 2009} & $18.4 \mathrm{Aa}$ & $24.1 \mathrm{Aa}$ & $22.5 \mathrm{Ba}$ & 5.48 \\
\hline & \multicolumn{3}{|c|}{ Experiment 2} & \\
\hline December 2009 & $12.8 \mathrm{ABb}$ & $15.2 \mathrm{Ba}$ & $15.5 \mathrm{Ca}$ & 0.96 \\
\hline January 2010 & $17.2 \mathrm{Ab}$ & 22.1Aab & 28.2Aba & 2.72 \\
\hline February 2010 & $18.3 \mathrm{Ab}$ & 23.1Aab & $30.0 \mathrm{Aa}$ & 3.26 \\
\hline March 2010 & 16.9Ab & 14.7Bb & $23.4 \mathrm{Ba}$ & 2.20 \\
\hline April 2010 & 13.7Ab & $9.0 \mathrm{Cb}$ & $16.8 \mathrm{Ca}$ & 1.93 \\
\hline May 2010 & $7.0 \mathrm{Bb}$ & $6.6 \mathrm{Cb}$ & $15.0 \mathrm{Ca}$ & 2.02 \\
\hline
\end{tabular}

For each experiment, means followed by the same uppercase letter in the column and lowercase letter in the row do not differ significantly based on Student's $t$ test $(\mathrm{P}>0.05)$.

SEM - standard error of the mean. 
process is triggered at the cellular level by specific signs of development, by potentially lethal events, such as error at the DNA replication during cell division, and by external factors, such as competition for light, water deficit, deficiency or excess of nutrients, removal of leaf or tiller during grazing and plagues and diseases (Taiz \& Zeiger, 2009). Thus, the greater daily leaf senescence during the summer in relation to the fall (Table 3 ) is coherent with the greater tissue flow because of environmental conditions favorable to plant growth, keeping the number of live leaves per tiller relatively constant (Davies, 1988), characterizing a continuous flow of tissue renewal.

Leaves have a limited lifespan (Hodgson et al., 1981) and after some time, they invariably go under senescence. Thus, all the non-harvested or non-grazed material is soon lost by the senescence process (Bullock, 1996), which constitutes potential production losses (Hodgson, 1990). Pastures managed with post-grazing height of $70 \mathrm{~cm}$ present higher amount of leaves and leaf area index after grazing (Monteiro, 2011), thus determining greater quantity of nongrazed material, which probably resulted in greater daily leaf senescence in February 2009 and from December to May 2010 (Table 3).

In experiment 1 , the daily forage production was affected by post-grazing height $(\mathrm{P}=0.0007)$ and month of the year $(\mathrm{P}=0.0021)$. Higher values were obtained in pastures managed with post-grazing height of $70(183.4 \mathrm{~kg} / \mathrm{ha}$.day DM) and $50 \mathrm{~cm}$ (178.9 kg/ha.day DM), in relation to those managed at $30 \mathrm{~cm}(80.1 \mathrm{~kg} /$ ha.day DM). The daily forage production was higher in February (249.6 kg/ha.day DM) and March (201.5 kg/ha.day DM), reducing in April (91.2 kg/ha.day DM) and reaching a lower value in May 2009 (47.5 kg/ha.day DM).

In experiment 2, the daily forage production was affected by post-grazing height $(\mathrm{P}=0.0352)$ and month of the year $(\mathrm{P}<0.0001)$. Higher value was record in pastures managed with post-grazing height of $70 \mathrm{~cm}$ (145.6 kg/ha.day DM), intermediate in those managed at $50 \mathrm{~cm}(115.9 \mathrm{~kg} / \mathrm{ha}$.day DM) and lower in those managed at $30 \mathrm{~cm}$ ( $57.0 \mathrm{~kg} /$ ha.day DM). The daily forage production was elevated in December 2009 (101.4 kg/ha.day DM) and January 2010 (111.9 kg/ha.day DM). These values decreased in February (94.5 kg/ha.day DM), increased in March (123.7 kg/ha.day DM) and April (125.2 kg/ha.day DM) and dropped again in May (80.3 kg/ha.day DM).

In experiment 1 , the daily forage accumulation was affected by post-grazing height $(\mathrm{P}=0.0017)$ and month of the year $(\mathrm{P}=0.0024)$. Greater values were obtained in pastures managed with post-grazing height of 50
(153.1 kg/ha.day DM) and $70 \mathrm{~cm}(147.9 \mathrm{~kg} /$ ha.day DM), in comparison with those managed at $30 \mathrm{~cm}(58.0 \mathrm{~kg} / \mathrm{ha}$.day $\mathrm{DM})$. The daily forage accumulation was greater in February (214.9 kg/ha.day DM) and March (168.7 kg/ha.day DM), reducing in April (70.2 kg/ha.day DM) and reaching lower value in May 2009 (25.8 kg/ha.day DM).

In experiment 2, the daily forage accumulation was affected by post-grazing height $(\mathrm{P}=0.0456)$ and month of the year $(\mathrm{P}<0.0001)$. Greater values were recorded in pastures managed with post-grazing height of $70(119.7 \mathrm{~kg} / \mathrm{ha}$.day $\mathrm{DM})$ and $50 \mathrm{~cm}(101.1 \mathrm{~kg} / \mathrm{ha}$.day DM), in relation to those managed at $30 \mathrm{~cm}(42.2 \mathrm{~kg} / \mathrm{ha}$.day DM). The daily forage accumulation in December 2009 and January 2010 was of 86.9 and $85.0 \mathrm{~kg} / \mathrm{ha}$.day DM, respectively. These values decreased in February (66.3 kg/ha.day DM), increased in March (105.0 kg/ha.day DM) and April (112.1 kg/ha.day $\mathrm{DM})$ and reduced again in May (70.7 kg/ha.day DM).

The variations caused by post-grazing heights resulted in changes in the luminous environment that affected the processes of leaf and stem accumulation and leaf senescence, which determined the daily production and accumulation of forage. Thus, elevation in the post-grazing height resulted in greater daily production of leaves and stems (Table 2) and leaf senescence (Table 3), which caused greater production and daily forage accumulation. Yet, in the months when the weather conditions were favorable to growth (summer), coincidently with the period of plain plant growth, forage daily production and accumulation were higher. The reductions in these variables in February 2010 are a result of decrease in the water balance of this period (Figure 2) in function of decrease in precipitation (Figure 1). The water deficit reduces the turgor pressure against the cell wall, which negatively affects leaf expansion; stimulates the closure of stomata, which diminishes the absorption of carbon dioxide and transfer of heat to the atmosphere; and reduces the absorption of soil nutrients, especially nitrogen (Taiz \& Zeiger, 2009). In fact, Ribeiro et al. (2009) revealed that in adequate conditions of photoperiod, temperature and soil fertility, the elevation in the amount of water available can increase growth, and consequently, production of elephant grass forage. In March, when the rainfall and the water balance of the soil increase (Figures 1 and 2), the forage daily production and accumulation increased once more, to eventually diminish in the fall.

The daily forage accumulation provides subsides to estimate the relative potential of utilization of the forage produced by means of calculation of the growth fraction that did not undergo the senescence process. In experiment 1 , the potential of forage utilization was 
affected by the post-grazing height and time of the year interaction ( $\mathrm{P}=0.0322$ ). There were no differences between post-grazing heights in February 2009. In March, higher value was obtained in pastures managed with post-grazing height of $50 \mathrm{~cm}$, intermediate in those managed at $70 \mathrm{~cm}$ and lower in those managed at $30 \mathrm{~cm}$. These differences were gone in April and May (Table 4). Overall, the potential of forage utilization was higher from February to April, in relation to May.

In experiment 2, the potential of forage utilization was affected by post-grazing height $(\mathrm{P}=0.0284)$ and month of the year $(\mathrm{P}<0.0001)$. Pastures managed with post-grazing height of $70(82.2 \%)$ and $50 \mathrm{~cm}(86.0 \%)$ present higher values in comparison with those managed at $30 \mathrm{~cm}$ (73.0\%). This pattern was also observed in pastures managed with post-grazing height of 70 and $50 \mathrm{~cm}$ in March 2009 in experiment 1 (Table 4). Senescence and death of leaf tissues reduce the potential of utilization of the forage produced. Probably, the greater daily leaf senescence presented in these pastures (Table 3) compensated by the greater daily production of leaves and stems (Table 2 ) and consequently, of forage, promoted greater potential of forage utilization.

The potential of forage utilization was elevated in December 2009 (84.5\%). This value decreased in January (73.9\%) and February 2010 (68.8\%), increasing in March and reaching higher value in April (87.7\%) and May (86.9\%). In times when there was lower forage accumulation, months of fall in 2009 (Table 4) and February 2010, the potential of forage accumulation was also lower, in response to the lower pasture growth. The fall of 2010 was an exception, for in this period the potential of forage utilization was elevated, in comparison with the summer. Possibly, this pattern is a result of the elevated accumulation of stems recorded in this period, because of the flourishing of elephant grass.

Table 4 - Potential of forage utilization (\%) of elephant grass cv. Napier subjected to three post-grazing heights when reaching 95\% light interception during regrowth

\begin{tabular}{|c|c|c|c|c|}
\hline \multirow[t]{2}{*}{ Months } & \multicolumn{3}{|c|}{ Post-grazing heights (cm) } & \multirow[t]{2}{*}{ SEM } \\
\hline & 30 & 50 & 70 & \\
\hline & \multicolumn{3}{|c|}{ Experiment 1} & \\
\hline February 2009 & $83.0 \mathrm{Aa}$ & $90.1 \mathrm{Aa}$ & $83.1 \mathrm{Aa}$ & 2.44 \\
\hline March 2009 & $77.2 \mathrm{Ab}$ & $87.5 \mathrm{Aa}$ & 82.6Aab & 3.12 \\
\hline April 2009 & $66.1 \mathrm{Ba}$ & $81.4 \mathrm{Aa}$ & $80.0 \mathrm{Aa}$ & 5.33 \\
\hline May 2009 & $52.7 \mathrm{Ca}$ & 45.9Ba & $60.7 \mathrm{Ba}$ & 5.04 \\
\hline
\end{tabular}

Means followed by the same uppercase letter in the column and lowercase letter in the row do not differ significantly based on Student's $t$-test $(\mathrm{P}>0.05)$. SEM - standard error of the mean.

\section{Conclusions}

The elevation in post-grazing residue height, especially in the summer, increases the regrowth vigor of elephant grass cv. Napier pasture. This grass must not be managed with post-grazing height of $30 \mathrm{~cm}$.

\section{Acknowledgements}

To FAPEMIG, CNPq and to the Department of Animal Science of Universidade Federal de Viçosa for the opportunity and sponsorship of the first author.

\section{References}

ALCÂNTARA, P.B.; BUFARAH, G. Plantas forrageiras: gramíneas e leguminosas. 2.ed. São Paulo: Nobel, 1983. 150p. BIRCHAM, J.S.; HODGSON, J. The influence of sward condition on rates of herbage growth and senescence in mixed swards under continuous stocking management. Grass and Forage Science, v.38, p.323-331, 1983.

BRAGA, G.J.; De MELLO, A.C.L.; PEDREIRA, C.G.S. et al. Fotossíntese e taxa diária de produção de forragem em pastagens de capim-tanzânia sob lotação intermitente. Pesquisa Agropecuária Brasileira, v.44, n.1, p.84-91, 2009.

BROUGHAM, R.W. Effects of intensity of defoliation on regrowth of pasture. Australian Journal of Agricultural Research, v.7, p.377-387, 1956.

BULLOCK, J.M. Plant competition and population dynamics. In: HODGSON, J.; ILLIUS, A.W. (Eds.). The ecology and management of grazing systems. Wallingford: $\mathrm{CAB}$ International, 1996. p.69-100

CARNEVALLI, R.A.; DA SILVA, S.C.; BUENO, A.A.O. et al. Herbage production and grazing losses in Panicum maximum cV. Mombaca under four grazing managements. Tropical Grasslands, v.40, p.165-176, 2006.

COMISSÃO DE FERTILIDADE DO SOLO DO ESTADO DE MINAS GERAIS - CFSEMG. Recomendações para o uso de corretivos e fertilizantes em Minas Gerais: $5^{\text {a }}$ Aproximação. RIBEIRO, A.C.; GUIMARÃES, P.T.G.; ALVAREZ, V.H. et al. (Eds.). Viçosa, MG: UFV, 1999. 359p.

CORSI, M. Manejo de capim-elefante sob pastejo. In: SIMPÓSIO SOBRE MANEJO DA PASTAGEM, 10., 1993, Piracicaba. Anais... Piracicaba: FEALQ, 1993. p.143-168.

DA SILVA, S.C.; NASCIMENTO JÚNIOR, D. Avanços na pesquisa com plantas forrageiras tropicais em pastagens: características morfofisiológicas e manejo do pastejo. Revista Brasileira de Zootecnia, v.36, n.4, p.121-138, 2007 (supl. especial).

DAVIDSON, J.L.; MILTHORPE, F.L. Leaf growth of Dactylis glomerata L. following defoliation. Annals of Botany, v.30, p.173-184, 1966.

DAVIES, A. The regrowth of grass swards. In: JONES M.B.; LAZEMBY A. (Eds.). The grass crop: The physiological basis of production. London: Chapman and Hall, 1988. p.85-127.

DERESZ, F.; CÓSER, A.C.; MARTINS, C.E. Formação e utilização de pastagens de capim-elefante. 2.ed. Juiz de Fora: Embrapa Gado de Leite, 2006. 2p. (Instrução Técnica).

EMPRESA BRASILEIRA DE PESQUISA AGROPECUÁRIA EMBRAPA. Sistema brasileiro de classificação de solos. Brasília: EMBRAPA, 1999. 412p. (Produção de Informação).

GRANT, S.A.; MARRIOT, C.A. Detailed studies of grazed swardtechniques and conclusions. Journal of Agricultural Science, v.122, n.1, p.1-6, 1994. 
HODGSON, J. Grazing management: science into practice. New York: John Wiley and Sons, 1990. 203p.

HODGSON, J.; BIRCHAM, J.S.; GRANT, S.A. et al. The influence of cutting and grazing management on herbage growth and utilization. In: WRIGHT, C.E. (Ed.). Plant physiology and herbage production. Nottingham: British Grassland Society, 1981. p.51-62.

JACQUES, A.V.A. Caracteres morfofisiológicos e suas aplicações como manejo. In: CARVALHO, M.M.; ALVIM, M.J.; XAVIER, D.F. et al. (Eds.) Capim-elefante: produção e utilização. Coronel Pacheco: Embrapa-Gado de Leite, 1994. p.31-47.

KÖPPEN, W. Climatologia. Buenos Aires: Gráfica Panamericana, 1948. 478p.

KORTE, C.J.; HARRIS, W. Effects of grazing and cutting. In: SNAYDON, R.W. (Ed.). Ecosystems of the world: Managed grasslands analytical studies. Amsterdam: Elsevier Science Publisher, 1987. v.17, p.71-79.

LEMAIRE, G.; CHAPMAN, D. Tissue flows in grazed plant communities. In: HODGSON, J.; ILLIUS, A.W. (Eds.). The ecology and management of grazing systems. Wallingford: CAB International, 1996. p.3-36.

LITTEL, R.C.; PENDERGAST, J.; NATARAJAN, R. Modelling covariance structure in the analysis of repeated measures data. Statistics in Medicine, v.19, p.1793-1819, 2000.

MISLEVY, P.; MOTT, G.O.; MARTIN, F.G. Screening perennial forages by mob-grazing technique. In: INTERNATIONAL GRASSLAND CONGRESS, 14., 1983, Lexington. Proceedings... Boulder: Westview Press, 1983. p.516-519.

MONTEIRO, H.C.F. Estrutura do dossel, acúmulo de forragem e dinâmica do perfilhamento em pastos de capim-elefante cv. Napier submetido a estratégias de pastejo rotativo. 2011. 133f. Tese (Doutorado em Zootecnia) - Universidade Federal de Viçosa, Viçosa, MG.
NASCIMENTO JÚNIOR, D.; SANTOS, M.E.R.; SILVEIRA, M.C.T et al. Pesquisa com forrageiras de clima tropical: uma abordagem histórica. In: SIMPÓSIO SOBRE MANEJO ESTRATÉGICO DA PASTAGEM, 5., 2010, Viçosa, MG. Anais... Viçosa, MG: UFV, 2010. p.1-40.

PARSONS, A.J.; PENNING, P.D. The effect of the duration of regrowth on photosynthesis, leaf death and the average rate of growth in a rotationally grazed sward. Grass and Forage Science, v.43, n.1, p.15-27, 1988.

RAIJ, B.V.; QUAGGIO, J.A.; SILVA, N.M. Extraction of phosphorus, potassium, calcium, and magnesium from soils by ion-exchange resin procedure. Communications in Soil Science and Plant Analysis, v.17, n.5, p.547-566, 1986.

RIBEIRO, E.G.; FONTES, C.A.A.; PALIERAQUI, J.G.B. et al. Influência da irrigação, nas épocas seca e chuvosa, na produção e composição química dos capins Napier e Mombaça em sistema de lotação intermitente. Revista Brasileira de Zootecnia. v.38, n.8, p.1432-1442, 2009.

SALISBURY, F.B.; ROSS, C.W. Plant physiology. 4.ed. California: Wadsworth Publishing Company, 1992. 682p.

TAIZ, L.; ZEIGER, E. Fisiologia vegetal. 4.ed. Tradução de SANTARÉM, E.R. et al. Porto Alegre: Artmed, 2009. 848p.

THORNTHWAITE, C.W.; MATHER, R.J. The water balance. New Jersey: Laboratory of Climatology, v.8, 1955. 104p.

VAN SOEST, P.J. Nutritional ecology of the ruminant. 2.ed. New York: Cornell University Press, 1994. 476p.

WILMAN, D.; MARES MARTINS, V.M. Senescence and death of herbage during periods of regrowth in ryegrass and red and white clover, and the effect of applied nitrogen. Journal of Applied Ecology, v.14, p.615-620, 1977.

WOLFINGER, R.D. Covariance structure selection in general mixed models. Communications in Statistics Simulation and Computation, v.22, n.4, p.1079-1106, 1993. 